\title{
Enteropathogens in Under-Five Children with Diarrhea in Health Facilities of Debre Berhan Town, North Shoa, Ethiopia
}

\author{
Tizazu Zenebe Zelelie ${ }^{1 *}$, Demissew Shenkute Gebreyes ${ }^{2}$, Alemnesh Tesema \\ Tilahun $^{3}$, Hillary A. Craddock ${ }^{4}$, Nigus Zegeye Gishen ${ }^{1}$
}

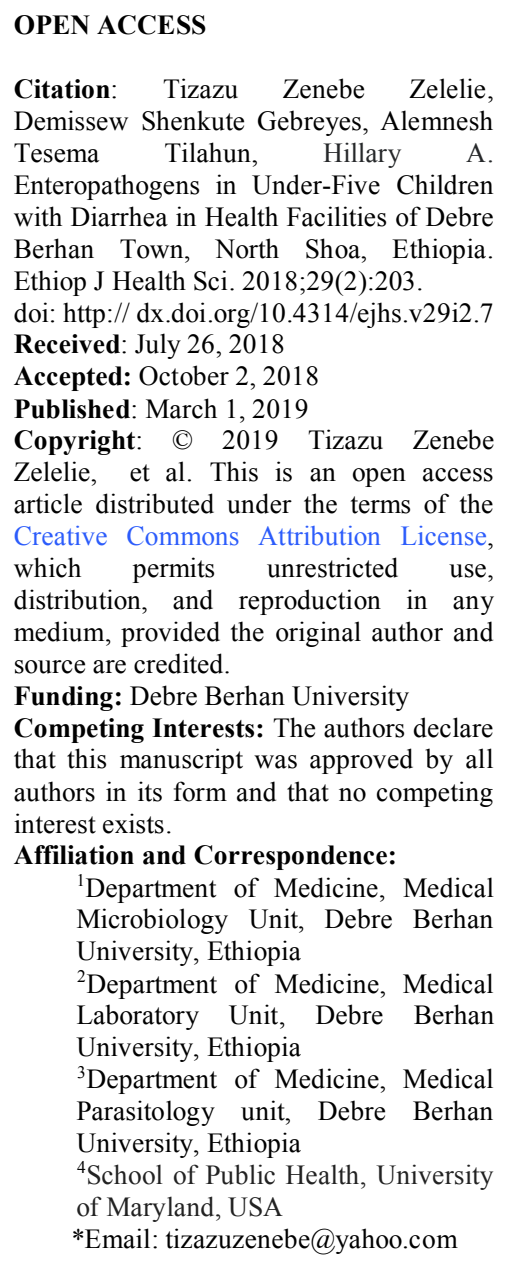

\section{ABSTRACT}

BACKGROUND: Diarrheal disease is a major cause of mortality and morbidity for under-five children in Ethiopia. The purpose of this study was to investigate the behavioral and socioeconomic risk factors, etiology, and drug susceptibility of bacteria isolated from under-five children with acute diarrhea who were treated at Debre Berhan Referral Hospital or Health Center in Ethiopia.

METHODS: A health facility based cross-sectional study design was used to investigate enteropathogens from 163 under-five children with acute diarrhea. After obtaining written consent from parents or guardians, data were collected using a standardized questionnaire. Freshly passed stool samples were collected for microbiological tests for bacteria and parasites. The chi-square test was used for assessing the relationships of variables.

RESULTS: Enteropathogens were detected among 55.8\% (91/163) participants. There was a $46 \%(75 / 163)$ bacterial culture positivity rate and a 9.8\%(16/163) prevalence of parasites. The isolated enteropathogens were Escherchia coli, Klebsiella specie, Proteus species, Salmonella species, Shigella species, Enterobacter species, Giardia lamblia, Enteameba histolytica, Ascaris lumbricoides, Trichuris trichiura and Hymnoleps nana. Level of antimicrobial resistance of bacterial isolates ranged from 0 to $87.2 \%$. Poor hand washing and poor cleaning of feeding utensils showed significant association with the presence of enteropathogens.

CONCLUSION: Bacterial enteropathogens with drug resistance were observed in this study. Continuous health education and promotion about diarrheal disease for mothers/caretakers and regular surveillance of entropathogenes are recommended to reduce under-five mortality. KEYWORDS: Under-five children, Diarrhea, enteropathogen, drug resistance, Ethiopia

\section{INTRODUCTION}

Infectious diarrheal diseases are of great concern, as they are responsible for three million deaths annually as well as considerable morbidity (1). In 2015, diarrhea was the $9^{\text {th }}$ leading cause of death globally, at about 1.3 million deaths per year, but the fourth leading cause in children of under-five years, with roughly 499,000 deaths (2). The highest mortality rate was in sub-Saharan Africa and 
Asia (2), and if this trend continues, it is estimated that 4.4 million children under the age of five will die from infectious diseases by 2030 (3). The World Health Organization (WHO) reported that Africa and South-East Asia account for $78 \%$ of all diarrheal deaths among children in the developing world. Sub-Saharan Africa, which includes Ethiopia, has the highest rates of child mortality due to diarrhea $(4,5)$. Poor environmental conditions, socioeconomic status and behavioral factors are all strongly associated with the risk of diarrheal disease transmission (6).

Although diarrhea is caused by a variety of infectious agents, bacterial enteropathogens are among the leading causes in developed and developing countries. Bacterial pathogens, including Escherchia coli, Shigella species, Salmonella species, Proteus species, Yersinia species, Vibrio cholera and Campylobacter species are some of the common infectious agents which cause enteric disease in under-five children (7-16). Intestinal parasitic infections are also common worldwide. It is estimated that 3.5 billion people around the world, the majority of which are children, are affected as a result of these infections. These infections cause diarrhea in 30$80 \%$ of patients, and the most common etiologic agents include Giardia lamblia, Entamoeba histolytica, Cyclospora cayetanensis, Cryptosporidium, Ascaris lumbricoides, Trichuris trichiura, Blastocystis hominis and Hymnolepis nana $(8,9,11,18,19,20)$.

One significant challenge regarding the treatment of diarrheal diseases is antimicrobial resistance due to indiscriminate use of antimicrobials (15). Many studies have shown that enteropathogens can develop such resistance. For example, resistance of E. coli, Salmonella species, Campylobacter species and Shigella species isolates to ampicillin and trimethoprimsulfamethazole has been observed (16). Many of these studies also show that resistance patterns can vary and change over time $(10,11,15,16,21$ 26).

In Ethiopia trends of percentage of children under the age five who had diarrhea in 2 weeks showed reduction, like for example from $24 \%$ in
2000 to $12 \%$ in 2016 (27). However, diarrhea is still one of the major contributors to death of children under the age five years $(28,29)$ with recently reported $22 \%$ prevalence of diarrhea in this age group in the country (29). Overall, Ethiopia has the fifth highest burden of pneumonia and diarrhea in the world (30). There has been substantial prior research on the prevalence and determinant factors of diarrhea, with several occurring in Ethiopia (6,31-35). These studies show that the frequency and severity of diarrhea could be aggravated by lack of sanitary disposal of human waste, inadequate feeding practices and hand-washing, poor housing conditions, and lack of access to adequate and affordable health care (31). In the country, only $57 \%$ and $4 \%$ of rural households have access to improved drinking water sources and improved toilet facility respectively (27).

Studies have been carried out in various parts of Ethiopia to investigate the influence of various behavioral factors on diarrheal illness. However, this study is novel in that it investigated behavioral and socioeconomic factors, etiological agents and antibiotic resistance among under-five children with acute diarrhea in health facilities of Debre Berhan town, Ethiopia.

\section{MATERIALS AND METHODS}

Study design: A health facility based, crosssectional study design was utilized. The study was conducted at the Debre Berhan Referral Hospital and Health Center in Debre Berhan, Ethiopia, between November 2015 and August 2016. Debre Berhan is a town in Central Ethiopia. Participants were recruited as they came to the Pediatric Outpatient Department for treatment of acute diarrhea. The sample size (N) was determined using the single population proportion formula: $\quad \mathrm{N}=\frac{\left(z_{\alpha / 2}\right)^{2} p(1-p)}{d^{2}}$, and based on assumptions of $Z \alpha / 2=1.96$ at the $95 \%$ level of confidence, taking higher margin of error, $\mathrm{d}=7.6 \%$ (because of resource limitation), prevalence of enteropathogens in under-five children $(\mathrm{P})=0.635(36)$ and $5 \%$ non response

DOI: http://dx.doi.org/10.4314/ejhs.v29i2.7 
rate. Ultimately, 163 children of under-five years of age were enrolled in the study. Data on general socio-demographic characteristics and acute diarrhea exposure factors were collected by a structured questionnaire, and fecal samples were collected for analysis from each patient. Additional clinical data were extracted from patient records.

\section{Sample Processing}

Stool sample collection and transportation: Stool samples were collected by trained nurses from children with acute diarrhea. These samples were collected in a sterile basin in the toilet. Each stool sample for bacterial isolation was immersed into a test tube containing Cary Blair medium (Oxoid). For parasite isolation, stool samples were collected in two additional sample cups, one with and one without $10 \%$ formol-saline. The samples were stored in an ice chest with ice packs and transported to the Microbiology Laboratory within two hours of collection. In most cases, the samples were processed immediately after arrival, and otherwise, they were stored at $-20^{\circ} \mathrm{C}$ until processing.

Isolation and characterization of bacteria: Stool samples were first plated onto supportive enrichment media (Blood agar and Selenite broth, both from Oxoid). Then the bacterial colonies were sub-cultured into a slightly selective and differential media (MacConkey agar and Eosin-methylene blue agar (EMB, from Oxoid). Finaly the colonies were sub-cultured onto a moderately selective media, Xylose Lysine Deoxycholate (XLD, from Oxoid), and Salmonella-Shigella (20). All were incubated at $37^{\circ} \mathrm{C}$ for 24 hours.

All the suspected isolates were tested via Gram staining method and examined biochemically using oxidase test, lysine decarboxylase test, urease test, citrate test, hydrogen sulfide gas production, fermentation test, and motility test to identify the significant characteristic of bacteria according to the standard methods $(19,37)$. Based on culture results and microscopic and biochemical characteristics, bacterial isolates were identified to the genus level.
Antimicrobial susceptibility patterns were determined by disk diffusion, which was done according to the guideline of Clinical and Laboratory Standards Institute (CLSI) (38). The antibiotics tested against bacteria were the commonly prescribed antibiotics. These were

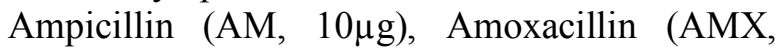
$10 \mu \mathrm{g})$ Cephalothin (CF, $30 \mu \mathrm{g})$,

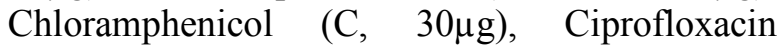
(CIP, $5 \mu \mathrm{g})$, Gentamycin (GM, 10 $\mu \mathrm{g})$, Nalidixic acid (NA, 30 $\mu \mathrm{g}$ ), Ceftriaxone (CRO), Tetracycline (TE) and TrimethoprimSulphamethazole (SX). According to the size of the zone of inhibition, the organisms were classified as sensitive, intermediately sensitive, or resistant to each antibiotic using CLSI interpretation guideline (38).

Isolation and characterization of parasites: Microscopic examination of stool was done by preparing a slide using Normal Saline and Lugol's Iodine to observe the ova, cysts and trophozoite stage of the parasites present in the stool. Samples were examined under a magnification of $40 \mathrm{x}$ to detect ova and cysts of parasites, and parasites were identified to the species level (37).

Quality control: The researchers strictly adhered to Standard operating procedures (SOPs) during sample processing. Sterility tests were done for prepared culture media. Control organisms (Escherichia coli ATCC 25922, Staphylococcus aureus ATCC 25923 and Pseudomonas aeruginosa ATCC 27853) were used in each relevant procedure.

Data management and analysis: Data were entered and analyzed using SPSS version 20 software. The magnitude (prevalence) of each enteropathogen was summarized. Variables with a p-value of $\leq 0.05$ were considered a statistically significant.

Ethics approval: Ethical clearance was obtained from the Ethics Review Committee of the Research and Community Service of Debre Berhan University. Official letter was given to the health facilities to create a smooth environment. Written informed consent was obtained from each child's parent or guardian. The results were communicated to the attending physician for providing treatment for children with diarrhea.

DOI: http://dx.doi.org/10.4314/ejhs.v29i2.7 


\section{RESULTS}

Socio-demographic factors: A total of 163 under-five children with acute diarrhea were included in the study. About 92(56.4\%) of the children came from Debre Berhan, and the rest $(43.6 \%)$ were from outside the town. About twothirds $(68.1 \%)$ of the guardians or parents were females, and the majority (96.9\%) of the guardians or parents were married. Sociodemographic data of the guardians or parents are presented in Table 1. The mean age of the study participants was 1.6 years (SD \pm 1.032 ). Further socio-demographic and clinical data are presented in Table 2.

Table 1: Socio-demographic data of the guardians or/parents in two Debre Berhan Health Facilities from November 2015 to August 2016.

\begin{tabular}{llcc}
\hline $\begin{array}{l}\text { Variablefor the } \\
\text { guardian/parents }\end{array}$ & \multicolumn{1}{c}{ Response } & Frequency & Percent (\%) \\
\hline Marital status & Currently married & 158 & 96.9 \\
Religion & Currently single & 5 & 3.1 \\
& Orthodox & 117 & 71.8 \\
& Muslim & 26 & 16.0 \\
Ethnicity & Protestant & 20 & 12.3 \\
& Amhara & 98 & 60.1 \\
& Oromo & 28 & 17.2 \\
Educational status & Tigre & 37 & 22.7 \\
& Illiterate & 21 & 12.9 \\
& Primary school & 19 & 11.7 \\
& Secondary school & 22 & 13.5 \\
Work status & College or university & 101 & 62.0 \\
& Unemployed & 26 & 16.0 \\
& Daily worker & 17 & 10.4 \\
& Monthly salary & 72 & 44.2 \\
& Others ${ }^{1}$ & 48 & 29.4 \\
\hline
\end{tabular}

Table 2: Socio-demographic and clinical data of under-five children who presented to two Debre Berhan, Ethiopia Health Facilities from November 2015 to August 2016.

\begin{tabular}{|c|c|c|c|}
\hline Variables for the child & & Frequency & Percentage \\
\hline \multirow[t]{2}{*}{ Sex } & Male & 99 & $60.7 \%$ \\
\hline & Female & 64 & $39.3 \%$ \\
\hline \multirow[t]{3}{*}{ Age in months } & $0-12$ & 75 & $46.0 \%$ \\
\hline & $13-24$ & 52 & $31.9 \%$ \\
\hline & $25-60$ & 36 & $22.1 \%$ \\
\hline \multirow[t]{2}{*}{ Fever } & No & 78 & $47.9 \%$ \\
\hline & Yes & 85 & $52.1 \%$ \\
\hline \multirow[t]{3}{*}{ Stool appearance } & Bloody & 18 & $11.0 \%$ \\
\hline & Mucoid & 82 & $50.3 \%$ \\
\hline & Watery & 63 & $38.7 \%$ \\
\hline \multirow{2}{*}{$\begin{array}{l}\text { Treatment in the last two } \\
\text { weeks }\end{array}$} & No & 103 & $63.2 \%$ \\
\hline & Yes & 60 & $36.8 \%$ \\
\hline
\end{tabular}

${ }^{1}$ Other includes farmer, merchant, students

DOI: http://dx.doi.org/10.4314/ejhs.v29i2.7 
Associated variables related to child diarrhea were assessed, and it was found that only handwashing practices and poor cleaning of utensils used in feeding the child were statistically significant for the presence of enteropathogens in stool samples (Table 3).

Table 3: Results of chi-squared test comparing socioeconomic and demographic factors to diarrhea outcomes in under-five children who presented to two Debre Berhan, Health Facilities from November 2015 to August 2016

\begin{tabular}{|c|c|c|c|c|c|c|}
\hline Variables & $\begin{array}{l}\text { Enteropathogen } \\
(\mathrm{n}=91), \mathrm{n}(\%)\end{array}$ & P-value & $\begin{array}{l}\text { Bacterial } \\
\text { isolates }\end{array}$ & P-value & Parasites & P-value \\
\hline \multicolumn{7}{|l|}{ Hand washing practice } \\
\hline Poor & $58(77.3 \%)$ & $\mathbf{P}=\mathbf{0 . 0 0 0}$ & $43(57.3 \%)$ & $P=0.006$ & $15(20.0 \%)$ & $P=0.000$ \\
\hline Good & $33(37.5 \%)$ & & $32(36.4 \%)$ & & $1(1.1 \%)$ & \\
\hline \multicolumn{7}{|l|}{ Defecation site } \\
\hline Traditional pit latrine & $63(62.4 \%)$ & $\mathrm{P}=0.099$ & $51(50.5 \%)$ & $\mathrm{P}=0.338$ & $12(11.9 \%)$ & $\mathrm{P}=0.488$ \\
\hline Ventilated pit latrine & $17(44.7 \%)$ & & $15(39.5 \%)$ & & $2(5.3 \%)$ & \\
\hline Open field & $11(45.8 \%)$ & & $9(37.5 \%)$ & & $2(8.3 \%)$ & \\
\hline \multicolumn{7}{|c|}{ Latrine cleaning frequency } \\
\hline Every day & $12(52.2 \%)$ & $\mathrm{P}=0.188$ & $10(43.5 \%)$ & $\mathrm{P}=0.294$ & $2(8.7 \%)$ & $\mathrm{P}=0.904$ \\
\hline 1-2 times per week & $27(47.4 \%)$ & & $22(38.6 \%)$ & & $5(8.8 \%)$ & \\
\hline Not cleaned & $52(62.7 \%)$ & & $43(51.8 \%)$ & & $9(10.8 \%)$ & \\
\hline \multicolumn{7}{|c|}{ Contact with domestic animals } \\
\hline No & $39(54.2 \%)$ & $\mathrm{P}=0.412$ & $34(47.2 \%)$ & $\mathrm{P}=0.457$ & $5(6.9 \%)$ & $\mathrm{P}=0.204$ \\
\hline Yes & $52(57.1 \%)$ & & $41(45.1 \%)$ & & $11(12.1 \%)$ & \\
\hline \multicolumn{7}{|c|}{ Cleaning of utensil for child feeding } \\
\hline Poor & $59(83.1 \%)$ & $P=0.000$ & $44(62.0 \%)$ & $P=0.000$ & $15(21.1 \%)$ & $P=0.000$ \\
\hline Good & $32(34.8 \%)$ & & $31(33.7 \%)$ & & $1(1.1 \%)$ & \\
\hline
\end{tabular}

Enteropathogens in under-five children: Enteropathogens were detected from 91(55.8\%) of the 163 stool samples from children and infants. There was $46 \%(75 / 163)$ culture positivity and $9.8 \%(16 / 163)$ prevalence of parasites. The most predominant bacterial isolate was Escherchia coli $(62.7 \%)$, followed by Klebsiella specie (14.7\%), Proteus species (9.7\%), Salmonella species (6.7\%), Shigella species (4\%) and Enterobacter species (2.7\%) (Table 4). The isolated parasites were Giardia lamblia, Enteameba histolytica, Ascaris lumbricoides, Trichuris trichiura and Hymnoleps nana. The prevalence varied based on the clinical presentation of diarrhea. In bloody diarrhea cases, Giardia and Shigella were the most common. In samples with watery diarrhea, E. coli was the most common, and in mucoid diarrhea cases, Klebsiella and Proteus were the most common. Overall enteropathogens prevalence is indicated in Table 4.
Antimicrobial susceptibility test results: Overall, antimicrobial resistance of the isolates ranged from 0 to $87.2 \%$. High resistance was seen to ampicillin, tetracycline, nalidixic acid and trimethoprim-Sulphamethazole. With the exception of two $E$. coli isolates, all samples were susceptible to Ciprofloxacin. E. coli showed more resistance to antibiotics; however, there was a wide range of resistance. For example, $4.3 \%$ of the samples were resistant to Ciprofloxacin, while $87.2 \%$ of the samples were resistant to Trimethoprim-sulphamethazole. As seen in Table 3 , the other pathogens also exhibited a wide range of resistance. Salmonella species ranged from 0$80 \%$ resistance, $0-66.7 \%$ in Shigella species, 0 $81.8 \%$ in Klebsiella species, $0-57.1 \%$ in Proteus species and 0-50\% in Enterobacter species.

The majority of the bacterial isolates were resistant to more than three antibiotics. Overall, thirteen, two and one distinct antibiogram (resistance pattern) were observed in Escherchia

DOI: http://dx.doi.org/10.4314/ejhs.v29i2.7 
coli, Salmonella species, and Klebsiella species respectively (Table 5). The resistance pattern of Escherchia coli varied from 3-6 drugs. Forty of the total $E$. coli isolates were multi-drug resistant (resistant to 3 or more drugs). Two of the
Salmonella species and five Klebsiella species isolates were multi-drug resistant. Shigella species, Proteus species and Enterobacter species did not show antibigram patterns.

Table 4: Prevalence of pathogens in stool from under-five children who presented to two Debre Berhan, Health Facilities from November 2015 to August 2016.

\begin{tabular}{|c|c|c|c|c|}
\hline Pathogen & $\begin{array}{l}\text { Samples } \\
\text { testing } \\
\text { positive } \\
(\mathrm{n}=91)\end{array}$ & $\begin{array}{l}\text { Samples testing } \\
\text { positive } \quad \text { with } \\
\text { bloody diarrhea } \\
(\mathrm{n}=18)\end{array}$ & $\begin{array}{l}\text { Samples testing } \\
\text { positive with } \\
\text { watery diarrhea } \\
(\mathrm{n}=63)\end{array}$ & $\begin{array}{l}\text { Samples testing } \\
\text { positive with mucoid } \\
\text { stool appearance } \\
(\mathrm{n}=82)\end{array}$ \\
\hline Eschechia coli & $47(51.6 \%)$ & $7(38.9 \%)$ & $31(49.2 \%)$ & $9(11.0 \%)$ \\
\hline Salmonella spp & $5(5.5 \%)$ & $1(5.5 \%)$ & $1(1.6 \%)$ & $2(2.4 \%)$ \\
\hline Shigellaspp & $3(3.3 \%)$ & $3(16.6 \%)$ & 0 & 0 \\
\hline Klebsiellaspp & $11(12.1 \%)$ & 0 & $8(12.7 \%)$ & $3(3.6 \%)$ \\
\hline Proteus spp. & $7(7.7 \%)$ & 0 & $4(6.3 \%)$ & $3(3.6 \%)$ \\
\hline Enterobacter spp. & $2(2.2 \%)$ & 0 & $2(3.2 \%)$ & 0 \\
\hline Giardia lamblia & $5(5.5 \%)$ & $3(16.6 \%)$ & $2(3.2 \%)$ & 0 \\
\hline Enteamebahistolytica & $4(4.4 \%)$ & 0 & $2(3.2 \%)$ & $2(2.4 \%)$ \\
\hline Ascarislumbricoides & $3(3.3 \%)$ & 0 & 0 & $3(3.6 \%)$ \\
\hline Trichuristrichiura & $2(2.2 \%)$ & 0 & 0 & $2(2.4 \%)$ \\
\hline Hymnoleps nana & $2(2.2 \%)$ & 0 & 0 & $2(2.4 \%)$ \\
\hline
\end{tabular}

Table 5: Antibiotic resistance of bacterial isolates from stool samples from November 2015 to August 2016.

\begin{tabular}{|c|c|c|c|c|c|c|c|c|c|c|}
\hline \multirow[t]{2}{*}{ Name of isolates } & \multicolumn{10}{|c|}{ Number of strains (\%) resistance to antibiotics } \\
\hline & AMX & $\mathrm{AM}$ & $\mathrm{C}$ & $\mathrm{CF}$ & CIP & GM & $\mathrm{CRO}$ & TE & NA & SX \\
\hline Eschechia coli & $\begin{array}{l}5 \\
(10.6)\end{array}$ & $\begin{array}{l}29 \\
(61.7)\end{array}$ & $\begin{array}{l}20 \\
(42.6)\end{array}$ & $8(17)$ & $2(4.3)$ & $\begin{array}{l}10 \\
(21.3)\end{array}$ & $4(8.5)$ & $\begin{array}{l}38 \\
(80.8)\end{array}$ & $\begin{array}{l}7 \\
(14.9)\end{array}$ & $41(87.2)$ \\
\hline Salmonella species & $2(40)$ & $0(0)$ & $0(0)$ & $0(0)$ & $0(0)$ & $1(20)$ & $0(0)$ & $2(40)$ & $4(80)$ & $2(40)$ \\
\hline Shigella species & $0(0)$ & $1(33.3)$ & $1(33.3)$ & $0(0)$ & $0(0)$ & $(0)$ & $0(0)$ & $2(66.7)$ & $0(0)$ & $1(33.3)$ \\
\hline Klebsiella species & $4(36.4)$ & $3(27.3)$ & $2(18.2)$ & $2(18.2)$ & $0(0)$ & $4(36.4)$ & $0(0)$ & $9(81.8)$ & $1(9.1)$ & $8(72.7)$ \\
\hline Proteus species & $3(42.9)$ & $2(28.6)$ & $1(14.3)$ & $0(0)$ & $0(0)$ & $3(42.9)$ & $1(14.3)$ & $2(28.6)$ & $4(57.1)$ & $2(28.6)$ \\
\hline Enterobacter species & $0(0)$ & $1(50)$ & $0(0)$ & $0(0)$ & $0(0)$ & $1(50)$ & $0(0)$ & $0(0)$ & $1(50)$ & $0(0)$ \\
\hline
\end{tabular}

AMX: Amoxicillin; NA: Nalidixicaci; AM: Ampicillin; CF: Cephalothin; TE: Tetracycline; C: Chloramphenicol; CIP: Ciprofloxacin; SXT: Trimethoprim-Sulphamethazole; GM: Gentamicin; CRO: Ceftriaxone

Table 6: Multi-drug resistance antibiogram pattern of bacterial isolates in two Debre Berhan, Health Facilities from November 2015 to August 2016

DOI: http://dx.doi.org/10.4314/ejhs.v29i2.7 


\begin{tabular}{lll}
\hline Isolates & Resistance antibiogram & Number \\
\hline Eschechia coli & CIP, NA, SX & 2 \\
C, TE, SX & 10 \\
& AMX, CRO, NA, SX & 2 \\
AMX, AM, C, TE & 2 \\
AM, GM, TE, SX & 4 \\
C, TE, NA, SX & 2 \\
AM, C, CRO, TE & 2 \\
CF, CIP, GM, TE & 2 \\
AMX, AM, CF, TE, NA & 2 \\
Salmonella species & AMX, AM, CRO, TE, NA & 2 \\
Klebsiella species & AM, C, CF, TE, NA & 2 \\
& AM, C, GM, TE, SX & 6 \\
& AM, CIP, GM, TE, NA, SX & 2 \\
\hline
\end{tabular}

AMX: Amoxicillin; NA: Nalidixicaci; AM: Ampicillin; CF: Cephalothin; TE: Tetracycline; C: Chloramphenicol; CIP: Ciprofloxacin; SXT: Trimethoprim-Sulphamethazole; GM: Gentamicin; CRO: Ceftriaxone

\section{DISCUSSION}

Diarrhea remains one of the major illnesses in under-five children, and enteropathogens play significant roles as etiologic agents. In this study, the burden of bacterial and parasitic agents in children suffering from diarrhea, drug susceptibility pattern of bacterial isolates, and social and behavioral factors were investigated. This study additionally builds and expands on a previous study done in the area (6). However, the previous study did not investigate hand-washing or the washing of utensils used for feeding; so we are unable to compare these findings directly. On the other hand, another study done in Addis Ababa revealed that hand-washing with soap after defecation and before preparing food was associated with acute diarrhea (39). In agreement to this, the present study found that hand-washing is associated with occurrence of enteropathogens.

Since contact with domestic animals was associated with disease in the previous study (6), it was an unexpected finding that was not significant in this study. Agriculture is common practice around Debre Berhan that may result to have contact with domestic animals. And also a 2013 study found that $83 \%$ of diarrheatic lambs in the area tested positive for E. coli (34). Other studies also found association between domestic animal contact and diarrheal disease (40). This unexpected finding may be due to the season in which data were collected. For example, children may be in greater contact with animals during different times of the year.

Two new aspects of the present study include testing for specific bacteria and parasites as well as the testing of bacterial isolates for antibiotic resistance. Enteropathogens were detected in $55.8 \%$ of the patients in this study.

Specifically, regarding the prevalence of bacteria, studies in other parts of the world show more variation, with some reporting rates similar to those seen here, some reporting lower rates $(23,41-44)$ and some reporting higher rates (4547). The most similar rates were from Tanzania, 67.1\%(23), Mozambique, 42.2\%(41), Palestine, $57.9 \%(42)$ and Burkina Faso (24). However, it contradicts with another report from Trinidad by Zobida, et al (43), which found a prevalence of $17.4 \%$. This may be due to differences in handling of the specimens prior to processing, a true difference in the prevalence, or seasonal variation. For example, our study was conducted in the rainy season in a town surrounded by pastoral land.

DOI: http://dx.doi.org/10.4314/ejhs.v29i2.7 
Despite the relatively high prevalence of bacterial infection observed in our study, low prevalence $(9.8 \%$ ) of parasitic infections was seen among children with acute diarrhea. This finding agrees with studies done in Trinidad (43), the United Arab Emirates (48), Nigeria (46) and others $(11,49)$. However, there are other studies that reported a high prevalence of parasitic infections in Ethiopia $(33,50)$ plus in Tanzania (23) and Burkina Faso (45).

The low prevalence of parasitic infection in the present study could again be due to differences in study methodology, types of enteropathogen assayed in the study, true difference of the parasitic infection in the area and seasonal variations. Among parasitic infections, Girdia lambilia and Entameoba histolytica were relatively higher than other parasites, including helminths. This may be because of their nature for easily transmitting in the community.

In most areas of developing countries, regional knowledge of antibiotic resistance profiles among various bacterial isolates would be highly valuable, as it can help inform antibiotic choices by healthcare professionals. The rate of resistance observed here was consistent with other studies $(10,11,21,23,25)$. Significant resistance rate has been found to Tetracycline and Trimethoprim-sulfamethazole. One significant challenge was that the most common bacterial agent, E. coli, also exhibited the most resistance. The observed high multi-drug resistance of $E$. coli is comparable with other studies $(10,23)$. As $E$. coli is more resistant, it may be difficult to treat and requires careful decision at choice of antibiotics. Isolates of $E$. coli that showed low resistance to amoxacillin, cephalothin, ciprofloxacin and ceftriazone were detected. In the present study, multi-drug resistance to $E$. coli, however, would be crucial to choose such treatment with care, lest E. coli become widely resistant to these antibiotics as well.

The high resistance of bacterial isolates in this study may be due to misuse of therapeutic doses of commonly available antibiotics and the result of widespread use of antibiotics in agriculture, as antibiotic resistant $E$. coli have also been found on meat in abattoir studies in Ethiopia (51). The rates of resistance among Salmonella spp to Amoxacillin (40\%), Tetracycline (40\%), Nalidxic acid (80\%) and Trimethoprim-sulfamethazole were found to be high which is consistent with other studies $(10,16,24)$ but contradicts with the study done by Frederique (25). The difference may be the study period in that resistant species may be emerging through time. Two multi-drug resistant Salmonella spp were found. Similarly, Shigella spp showed resistance to Ampicilin (33.3\%), Chloroamphenicol (33.3\%), Tetracycline (66.7\%) and Trimethoprim-sulfamethazole (33.3\%), and this is a similar finding with other reports $(23,24,25)$.

Entropathogens were not detected in $44.2 \%$ of the study participants. This could be due to potential enteric pathogens such as viruses like norovirus and bacteria that were not tested for, such as Campylobacter spp, and Yersinia spp. Therefore, a possible limitation was the fact that the study design assayed for a limited selection of bacteria and parasites. It is possible that viral agents or other bacteria and parasites may also be important in childhood diarrhea in the area, and this question needs further investigation.

Further limitations of the study stem from the cross-sectional design. Other studies in Ethiopia have found that non-symptomatic carriage of intestinal parasites and various bacterial pathogens is common among adults (52). Thus, it is possible that the pathogens found were not the direct cause of the diarrhea. Additionally, lack of a control group makes it difficult to determine how significantly the various factors contributed to illness risk.

In conclusion, it was observed from this study that $E$. coli is predominant amongst other enteropathogens detected in children with diarrhea. It also found relatively low prevalence of Salmonella species, Shigella species, and parasites. High rate of resistance and many multi-drug resistant bacteria isolates were found. The isolation of enteropathogens was statistically associated with poor hand washing practices and 
poor cleaning of utensils used to feed the children. However, a more extensive communitybased cohort study is needed in order to explore the etiologic importance of this pathogen in diarrheic children. Education and outreach are critical components to reducing the burden of diarrhea observed in this study. Healthcare providers, veterinarians and farmers could work together to reduce unnecessary use of antibiotics in order to reduce the risk of resistance. It is important to continue surveillance on these microorganisms.

\section{ACKNOWLEDGMENTS}

We thank the staffs of Debre Berhan kebele 04 health centers and the referral hospital for their cooperation during data collection. We are grateful to the study participants and their caregivers. Lastly, we thank Debre Berhan University for funding the research.

\section{REFERENCE}

1. Jafari F, Shokorzadeh L, Hamidian M, Salmanzadeh-Ahrabi S, Zali MR. Acute diarrhea due to enteropathogenic bacteria in patients at hospital in Tehran. Jpn.J. Infect. Dis. 2008; 61: 269-73.

2. Gill CJ, Thea DM, Hibberd P. Diarrhoeal disease trends in the GBD 2015 study: optimism tempered by scepticism. The Lancet Infectious Diseases. 2017;17(9):884-5.

3. Liu L, Oza S, Hogan D, Perin J, Rudan I, Lawn JE, et al. Global, regional, and national causes of child mortality in 2000-13, with projections to inform post-2015 priorities: an updated systematic analysis. Lancet. 2015;385 (9966): 430-440.

4. Ramana J, Tamanna. Diarrhea: the database of pathogen proteins and vaccine antigens from diarrheal pathogens. Infect Genet Evol. 2012; 12(8):1647-51.

5. UNICEF. Level and trends in child mortality: New York: 2011.

6. Mamo A, Hailu A. Assessment of Prevalence and Related Factors of Diarrheal Diseases among Under-Five Year's Children in Debre Birehan Referral Hospital, Debre Birehan
Town, North Shoa Zone, Amhara Region, Ethiopia. OALib. 2014; 1: 1-14.

7. Kumari S, Kumar AS. Isolation of Microorganism from Stool Sample of Diarrhea Patient and Effect of Antibiotics and Herbal Extract. J Microbiol. 2013; 2 (2):2432.

8. Kayser HF, Bienz AK, Eckert J. Medical Microbiology. $10^{\text {th }}$ ed. New York: ThiemeStuttgart ; 2005

9. David AS, Robert N, Eileen H. Technically literature updates on diarrhea. WHO 1993; $8(1): 1-5$.

10. Manikandan C, Amsath A. Antimicrobial Resistance Of Enteric Pathogens Isolated From Children With Acute Diarrhoea In Pattukkottai, Tamil Nadu, India. Int. J. Pure Appl. Zool. 2013;1(2): 139-45.

11. Dooki, MR, Rajabnia R, Sawadkohi RB, Gatabi ZM, Poornasrollah M, Mirzapour M. Bacterial entropathogens and antimicrobial susceptibility in children with acute diarrhea In Babol, Iran. Caspian J Intern Med. 2014; 5(1): 30-34.

12. Soltan-Dallal M. Diarrhea Caused By Enteropathogenic Bacteria in Children. Arch Irn Med. 2001; 4 (4): 201-3.

13. Jackson J, Farone AL, Farone MB. Bacterial enteropathogens associated with diarrhea in a rural population of Haiti. Res Rep Trop Med.. 2011; 2: 129-33.

14. Svenungsson B, Lagergren A, Ekwall E, Evengård $\mathrm{B}$, Hedlund $\mathrm{KO}$, Kärnell $\mathrm{A}$, et al. Enteropathogens in Adult Patients with Diarrhea and Healthy Control Subjects: A 1Year Prospective Study in a Swedish Clinic for Infectious Diseases. Clin Infect Dis. 2000; 30:770-8.

15. Temu MM, Kaatano GM, Miyaye ND, Buhalata SN, Shushu ML, Kishamawe C, et al. Antimicrobial susceptibility of S. flexneri and S. dysenteriae isolated from stool specimens of patients with bloody diarrhoea in Mwanza, Tanzania. Tanzan Health Res Bull. 2007; 9(3):186-9.

16. Randrianirina F, Ratsima EH, Ramparany L, Randremanana R, Rakotonirina HC, Andriamanantena $\mathrm{T}$, et al. Antimicrobial resistance of bacterial enteropathogens

DOI: http://dx.doi.org/10.4314/ejhs.v29i2.7 
isolated from stools in Madagascar.BMC Infect Dis. 2014;14 (1):104.

17. WHO. Control of tropical diseases. WHO, Geneva. 1998;1:1-5

18. Awole M, Gebre-selassie S, Kassa T, Gebre Kibru. Prevalence of intestinal parasites in south-western Ethiopia. Ethiop.Journal of Health Devevelopment. 2003; 17(1):71-8.

19. World Health Organization: WHO, Integrated Management of Childhood Illness (IMCI)WHO recommendations on the management of diarrhoea and pneumonia in HIV-infected infants and children. Geneva: World Health Organization. 2010;1-40.

20. WHO. Basic laboratory procedure in clinical bacteriology. World Health Organization $2^{\text {nd }}$ ed Geneva, 2003; 56-69.

21. Scarlett TC, Durham RW, Hall IH, Crosswicks RJ, Berkowitz JD, Burnham BS. Synthesis and cytotoxicity of cyanoboraneadducts of n6-benzoyladenine and 6-triphenylphosphonylpurine. Met Based Drugs. 2002; 9(1-2):19-32.

22. Pourmand A, Mazer-Amirshahi M, Jasani G, May L. Emerging trends in antibiotic resistance: Implications for emergency medicine. The American journal of emergency medicine. 2017 Aug 1;35(8):1172-6.

23. Moyo SJ, Gro N, Matee MI, Kitundu J, Myrmel $\mathrm{H}$, Mylvaganam $\mathrm{H}$, et al. Age specific aetiological agents of diarrhoea in hospitalized children aged less than five years in Dares Salaam, Tanzania. BMC Pediatrics. 2011;11 (1):19.

24. Bonkoungou IJ, Haukka K, Österblad M, Hakanen AJ, Traoré AS, Barro N, et al. Bacterial and viral etiology of childhood diarrhea in Ouagadougou, Burkina Faso. BMC Pediatr. 2013; 13 (1):36. doi: 10.1186/1471-2431-13-36.

25. Randrianirina $\mathrm{F}$, Ratsima EH, Ramparany L, Randremanana R, Rakotonirina HC, Andriamanantena $\mathrm{T}$, et al. Antimicrobial resistance of bacterial enteropathogens isolated from stools in Madagascar. $B M C$ Infect Dis. 2014, 14 (1):104.

26. Ansari S, Sherchand JB, Parajuli K, Mishra SK, Dahal RK, Shrestha S, et al. Bacterial etiology of acute diarrhea in children under five years of age. J Nepal Health Res Counc. 2012 Sep; 10(22):218-23.

27. Central Statistical Agency. CSA, Ethiopia Mini Demographic and Health Survey 2016. Addis Ababa, Ethiopia. 2016; 1-551.

28. Deribew A, Tessema GA, Deribe K, Melaku YA, Lakew Y, Amare AT, et al. Trends, causes, and risk factors of mortality among children under 5 in Ethiopia, 1990-2013: findings from the Global Burden of Disease Study 2013. Population Health Metrics. 2016;14 (1):42.

29. Alebel A, Tesema C, Temesgen B, Gebrie A, Petrucka P, Kibret GD. Prevalence and determinants of diarrhea among under-five children in Ethiopia: A systematic review and meta-analysis. PLoS ONE. 2018; 13(6): e0199684.

30. IVAC. Pneumonia and Diarrhea Progress Report 2014. Retrieved from www.jhsph.edu/ivac.

31. Mohammed S, Tilahun M, Tamiru D. Morbidity and associated factors of diarrheal diseases among fewer than five children in Arba-Minch district, Southern Ethiopia. Science Journal of Public Health. 2013; 1(2): 102-6.

32. Tamiso A, Yitayal M, Awoke A. Prevalence and determinants of childhood diarrhoea among graduated households, in rural area of Shebedino district, Southern Ethiopia, 2013. Science Journal of Public Health. 2014;2(3): 243-51.

33. Teklemariam S, Getaneh T, Bekele F. Environmental determinants of diarrheal morbidity in under-five children, Keffa-Sheka zone, south west Ethiopia. Ethiop Med J.2000; 38(1):27-34.

34. Adamu H, EndashawT, TekaT, Kifle A, Petrose B. The prevalence of intestinal parasites in paediatricdiarrhoealand nondiarrhoeal patients in Addis Ababa

DOI: http://dx.doi.org/10.4314/ejhs.v29i2.7 
hospitals, with special emphasis on opportunistic parasitic infections and with insight into the demographic and socioeconomic factors. Ethiopian Journal of Health Development. 2006; 20(1):40-6.

35. Aklilu M, Sisay T, Tefera G, Tekalign B. Identification and Biotyping of Escherichia coli from Diarrheic Lambs in and Around Debre Birhan Town, Ethiopia. J Environ Anal Toxicol. 2013; 3(1):6.

36. Beyene G, Tasew H. Prevalence of intestinal parasite, Shigella and Salmonella species among diarrheal children in Jimma health center, Jimma southwest Ethiopia: a cross sectional study. Annals of Clinical Microbiology and Antimicrobials. 2014; 13:10.

37. Cheesbrough M. Medical Laboratory Manual for Tropical Countries, Part 2. $2^{\text {nd }}$ ed. London, UK. Cambridge University Press. 2006.

38. Clinical and Laboratory Standards Institute. Performance Standards for Antimicrobial Susceptibility Testing; Twenty-Fifth Informational Supplement. CLSI document M100-S25 (ISBN 1-56238-989-0 [Print]; ISBN 1-56238-990-4 [Electronic]). Clinical and Laboratory Standards Institute, 950 West Valley Road, Suite 2500, Wayne, Pennsylvania 19087 USA; 2015.

39. Adane M, Mengistie B, Mulat W, Medhin G, Kloos H. The most important recommended times of hand washing with soap and water in preventing the occurrence of acute diarrhea among children under five years of age in slums of Addis Ababa, Ethiopia. Journal of community health. 2018 Apr 1;43(2):400-5.

40. Zambrano LD, Levy K, Menezes NP, Freeman MC. Human diarrhea infections associated with domestic animal husbandry: a systematic review and meta-analysis. Trans $R$ Soc Trop Med Hyg. 2014; 108(6):313-25.

41. Mandomando IM, Macete EV, Ruiz J, Sanz $\mathrm{S}$, Abacassamo F, Valles X, et al. Etiology of Diarrhea in Children Younger Than 5 Years of Age Admitted In A Rural Hospital of Southern Mozambique. Am. J. Trop. Med. Hyg. 2007; 76(3): 522-27.
42. Abu Elamreen FH, Abed AA, Sharif FA. Detection and identification of bacterial enteropathogens by polymerase chain reaction and conventional techniques in childhood acute gastroenteritis in Gaza, Palestine. Int J Infect Dis. 2007; 11: 501-7.

43. Khan-Mohammed Z, Adesiyun AA, Swanston WH, Chadee DD. Frequency and characteristics of selected enteropathogens in fecal and rectal specimens from childhood diarrhea in Trinidad, 1998-2000. Rev Panam Salud Publica. 2005;17(3):170-7.

44. Purwar S, Bhattacharya D, Metgud SC, Kumar D, Chitambar SD, Roy S. A crosssectional study on aetiology of diarrhoeal disease, India. Indian $J$ Med Microbiol. 2016;34 (3):375-9.

45. Nitiema LW, Nordgren J, Ouermi D, Dianou $\mathrm{D}$, Traore AS, Svensson L, et al. Burden of rotavirus and other enteropathogens among children with diarrhea in Burkina Faso. Int J Infect Dis. 2011;15(9):646-52.

46. Akinnibosun FI, Nwafor FC. Prevalence of diarrhoea and antibiotic susceptibility test in children below 5 years at University of Benin Teaching Hospital, Nigeria. Int. Res. J. Public Environ. Health, 2015.

47. Rathaur VK, Pathania M, Jayara A, Yadav N. Clinical Study of Acute Childhood Diarrhoea Caused by Bacterial Enteropathogens. J ClinDiagn Res. 2014;8(5): PC01-PC05.

48. Dash N, Al-Zarouni M, Anwar K, Panigrahi D. Prevalence of intestinal parasitic infections in sharjah, United Arab Emirates. Human Parasitic Diseases. 2010;2: 21-4

49. Ansari S, Sherchand JB, Parajuli K, Paudyal BM, Adhikari RP, Shrestha S, et al. Pattern of Acute Parasitic Diarrhea in Children Under Five Years of Age in Kathmandu, Nepal. Open J Med Microbiol. 2012;2:95-100.

50. G/hiwot Y, Degarege A, Erko B. Prevalence of Intestinal Parasitic Infections among Children under Five Years of Age with Emphasis on SchistosomamansoniinWonjiShoa Sugar Estate, Ethiopia. PLoS ONE. 2014; 9(10): e109793. doi:10.1371/journal.pone.0109793.

DOI: http://dx.doi.org/10.4314/ejhs.v29i2.7 
51. Dulo F, Feleke A, Szonyi B, Fries R, Baumann MP, Grace D. Isolation of Multidrug resistant Escherichia coli O157 from goats in the Somali region of Ethiopia: A cross-sectional, abattoir-based study. Plos ONE. 2015; 10(11): e0142905.
52. Andargie G, Kassu A, Moges F, Tiruneh M, Huruy K. Prevalence of bacteria and intestinal parasites among food-handlers in Gondar town, northwest Ethiopia. $J$ Health PopulNutr. 2008; 26(4):451-55.

DOI: http://dx.doi.org/10.4314/ejhs.v29i2.7 